\title{
SERVICE-LEARNING IN SOCIAL WORK EDUCATION TO DEVELOP SOCIAL WORK COMPETENCIES IN UNIVERSITY STUDENTS
}

\author{
Monika Gruslyte \\ Klaipèda University, Lithuania
}

\begin{abstract}
The paper deals with service-learning as a teaching and learning approach in higher education being embedded in social work education seeking to achieve the synergy of the two reciprocally complementing and contributing phenomena. The aim of the theoretical investigation is to overview the concept of social work education as facilitated by service-learning to develop social work competencies in university students. The contribution of service-learning in delivering social work education curricula usually emphasises the development of core competencies and values in social work students, prospective professionals. The contemporary challenges, expectations and contextual demands are set for the social work profession both globally and locally. Therefore, the present research attempts to explore how the two concepts are bridged to meet for the development of social work competencies in university students and shares the insights on the implementation of this pedagogical approach in academic and broader community contexts.
\end{abstract}

Keywords: higher education; pedagogical approach; service-learning; social work competencies; social work education

To cite this article:

Gruslyte, M. (2021). Service-Learning in Social Work Education to Develop Social Work Competencies in University Students. Education. Innovation. Diversity, 2(2), 41-47.

DOI: https://doi.org/10.17770/eid2021.1.5427

\section{Introduction}

Service-learning, as a pedagogical approach bringing together students, academic staff and community members, is common throughout the world for several decades; however, some concerns are widely discussed in relation to the embedding of this educational method in higher education settings, attempting to "enrich and enhance higher education practices with students' competences and skills in bridging theory and practice, acquiring agency that potentially leads to a positive social change" (Gruslyte, 2020, 201). The present paper narrows down the focus of investigation specifying service-learning for the field of social work education in university studies and aims to explore how the two concepts bridge the fields seeking to generate synergy and positive social change.

Earlier research works on the adaptation of the initially American model of servicelearning to local (Lithuanian) socio-cultural and educational contexts (Mažeikis, 2007; Barzelis, Barcytè, \& Mažeikienė, 2008; Mažeikienė, Ruškus, \& Vandzinskaite, 2008; Vandzinskaite, 2011) have pointed out that it was being embedded to bridge the gap between theory and practice in university curricula and a combination of three elements, i.e. community service, purposeful academic learning, reflection, constituted the essence of this educational innovation (interchangeably called cooperative studies) (Mažeikienè, 2008, 8), reaching for students' improved competencies and skills, increased social awareness and agency as well as a positive social change, as the common good being constructed by the participants of this educational process. Recent theoretical and empirical investigations of service-learning as a holistic pedagogical approach aiming to develop students' work-life skills (communication, team-working and social skills as well as capacities in project-work, problem-solving, information literacy, communication, technological familiarity, time management, leadership), enhancing the integration of a pro-social disposition in young professionals-to-be, developing their civic-engagement competencies (Embedding ServiceLearning in Higher Education. Developing a Culture of Civic Engagement in Europe, 2019) 
put a stronger emphasis on the beneficial character of this pedagogy, closely investigating the contribution to all involved parties: students, the academia and communities. This is also under the scope of the present theoretical investigation, employing relevant literature review and a discussion to point out several negotiable aspects.

\section{Knowledge and Innovation for the Social Change}

Describing service-learning, researchers relate it to social constructivism, since it facilitates the building of people's competencies, their communal participation, civic activeness and engagement (Mažeikis \& Lenkauskaite, 2008, 30). The critical dimension in the servicelearning concept has been added in further stage of its scholarly development and relevant social contexts, in response to the emerging realities, social and academic demand as as well as prompting students "to think critically about social issues and act creatively to produce change" (Mitchell, 2007, 101), implement it as "the act of service, of community involvement that changes the traditional learning experience" (ibid., 107). Critical service-learning experiences, as advancement, may give students "a different perspective of the agency and its contribution to community, as well as a deeper understanding of the community served" (ibid., p. 108). The service-learning components 'learning to serve' and 'serving to learn' taking place within community and classroom are supplemented with 'a social change orientation', 'working to redistribute power' and 'developing authentic relationships' (Mitchell, 2008). Moreover, critical service-learning may be employed seeking to address the ways in which civic engagement can become repositioned and revitalised (Preradović \& Mažeikiené, 2019). The re-positioning of service learning as an educational technique and continuous innovation is one of the concerns connected to the assumed missions of higher education institutions operating in the broader social context.

Social work is treated as a global profession, putting emphasis on social work theory, curriculum design, social work practice and professional identity (Global Social Work: Crossing Borders, Blurring Boundaries, 2014). Characterising the issues which social workers face in various sociocultural contexts and cases of social workers' awareness and identity, Carolyn Noble and Mark Henrickson underline that "a philosophy of social work is dynamic, critical, and engaged with clients and the intersection of their multiple environments" (Noble \& Henrickson, 2014, 12). More specifically, writing about social work practice, Thomas O'Hare notices that "beginning social workers develop their knowledge and skills through both classroom learning and practice experience" (O'Hare, 2020 , p. ix). Further he adds: "The sources that have influenced the development of the essential skills curriculum in social work programs over the past century include theory, practice, wisdom, and tradition and, more recently, empirical research on the processes of psychosocial interventions and their relationships to client outcomes (...)" (ibid., 3). Moreover, overviewing the evolution of social work concept, David Howe calls social workers "raisers of consciousness" and "seekers after meaning" (Howe, 2016). These insights emphasise the multifaceted nature and character of social work education that integrates higher education and broader communities through implementation of servicelearning.

Acknowledging that service-learning, as a pedagogical and social innovation, originated in the American socio-educational contexts, it is worth referring to the educational policy and accreditation standards for social work curricula, as defined by the US Council of Social Work Education in this respect. Dealing with Baccalaureate and Master-level programmes, this organisation quite recently identified six dimensions in the discussed field: performance, knowledge, values, affective reactions, critical thinking, professional judgement (Council for Social Work Education [CSWE], 2015). These 
dimensions are overviewed by John Poulin and Selina Matis who emphasise a significant change in assessing the holistic competencies in social work students seeking in their future careers to provide competent social work to clients (Poulin \& Matis, 2015). In their view, the listed dimensions of competencies constitute, or circle around, the comprehensive competence (ibid.), though being drawn in a static manner.

Continuing the global discussion on service-learning and social work education processes and benefits, the reciprocity of the academia and communities making effect on and contributing to each other has been recently and relevantly broadcasted through the international webinar "How Can Universities Improve Their Social Impact" ([HCUITSI], 2021) bringing the issues of civic and ethical engagement, impact on communities, sensemaking of diverse expertise as well as knowledge and innovation support to the surface. This polylogue emphasised the need in building bridges between university communities and other communities, the impact of agency through academic research, engagement in solving realworld problems. Universities are globally viewed as anchor institutions, not just research institutions; the encouragement and expectation is expressed to go beyond that and create stronger leaders, communities, economies. Moreover, the said discussion revealed that the agency, engagement and research ought to be supplemented with wisdom as a higher purpose, i.e. to connect the knowledge systems; and, in this connection, there is an expressed call to create a model of social enterprise, to create solutions to occurring challenges.

\section{Specified Concept of Service-Learning in Social Work Education}

To develop the discussion on the essence and purpose of service-learning, scholars and practitioners try to highlight this pedagogical approach among other experiential learning practices. Discussions on the character and features of service-learning attempt to specify the concept of service-learning mostly focussing on the engagement, learning and contribution of the parties involved. Catherine M. Lemieux and Priscilla D. Allen call this phenomenon 'academic service-learning', underlining that it is "a pedagogical approach that integrates community service with academic study to promote student reflection, critical thinking, and creative problem solving" (Lemieux \& Allen, 2007, 309). They put emphasis on the importance of specification because the "definitions frame how student and community-oriented outcomes are conceptualized and operationalized" (ibid., 312). Another scholar, Andrew Furco, draws 'the balance beam' to locate five "service-focused experiential learning practices": volunteering and internship activities at the bottom level (meaning the recipients of the service benefit more in the case of volunteering; whereas, in the case of internship, a student (as a provider) focuses more on learning and benefits from it); the middle level includes community service and field education, with field education giving more educational benefit to a student, rather than community service stronger favouring recipients; and service-learning is depicted at the top, demonstrating that it encompasses, grounds on the features, practices and experiences of the other ones drawn below (Furco \& Norvell, 2019, 21). Moreover, the hyphen connecting the words and concepts 'service' and 'learning' reflects the reciprocity and mutual benefit to both, the recipient and the provider, service and learning, which are foundational to the concept encompassing the symbiotic relationship (ibid., 22).

In his book on service-learning, Dan W. Butin suggestively points out that "the service is not to benefit only the server (...). Not only should the server provide a meaningful and relevant service to those he is serving, but often members of the community being served should be the ones responsible for articulating what the service should be in the first place." (Butin, 2010, 5). The reciprocal character of learning from and in communities, academic and common society, as well as the awareness about this mutually 
contributing process develops the professional and personal competencies in students. This resonates with the social work competencies listed and defined in the recent EPAS standard for social work education, pointing them out but not limiting with them in the educational process: ethical and social behaviour, engagement in diversity and difference, concern about human rights and social, economic and environmental justice, engagement in policy practice, attention to individual, families, groups, organisation and communities (CSWE, 2015). The social work competencies are connected to the earlier mentioned six dimensions in social work. Moreover, in the EPAS standard, the emphasis is also put on one more reciprocal, interactive and symbiotic nature of service-learning in social work education: the practice-informed research and research-informed practice (CSWE, 2015). The latter aspect brings about not only the aspect of student learning but also the research component in the entire university education process and progress.

Recent scholarly negotiations in relation to the updating of the concept definition for a European socio-cultural context took place in the frame of an international project "Europe Engage", revealing an emerging "unique European version of service learning" (Furco \& Norvell, 2019, p. 32) and produced an updated quite extensive definition of service-learning:

Service-learning (sometimes referred to as community based or community engaged learning) is an innovative pedagogical approach that integrates meaningful community service or engagement into the curriculum and offers students academic credit for the learning that derives from active engagement within community and work on a real world problem. Reflection and experiential strategies underpin the learning process and the service is link to the academic discipline. Service learning brings together students, academics and the community whereby all become teaching resources, problem solvers and partners. In addition to enhancing academic and real world learning, the overall purpose of service learning is to instil in students a sense of civic engagement and responsibility and work towards positive social change within society. (ibid.)

This definition also echoes the global trends and experiences observed and gained throughout implementation of service-learning by higher education institutions, intentionally integrating curriculum with community service components, as underlined by C. M. Lemieux and P. D. Allen, "reestablishing higher educations' commitment to solving social problems in the communities in which such institutions reside" (Lemieux \& Allen, ibid.). Overviewing the elaborations on the integration of service-learning and social work education, they observe that "community-based learning is consistent with social work education approaches that model and teach empowerment-oriented practice", "social work education offers a prototype for service learning", "experiential and community-based models (...) have had a consistent presence in social work education", "all of social work education is service-learning" (ibid., 313). The interconnection of service-learning and social work is also elaborated by a number of other researchers in the field who emphasise that social work educators engage in service-learning as methodology and philosophy leading to a social change, renewal of both the academy and society, that "service-learning presents an opportunity for social work to reinforce its mission", for a student to be a community participant (Phillips, 2007, 8), treat service-learning as part of the social work curriculum through "the functioning of and interrelationships between social systems, the strengths perspective in practice, and empowerment" (Furuto, 2007, 22), emphasise collaborative responsibilities of the three service-learning partners (student, university, community) seeking to fulfill their expectations (Furuto, 2007), yet point out that "[i]nstitutions of higher education vary in their commitment to service learning" (Majewski, 2007, 46). The positioning of two elements of service-learning in delivery of social work education is linked to the intentional focus on either service or learning, also either reciprocity or 
separation (Campbell \& Bragg, 2007, 210-211). However, the researchers conclude that "[h]istorically, social work education has been grounded in experiential education, in developing social workers to improve communities and to take action based on the core values of the profession" (ibid., 217). Moreover, students are viewed as agents of social change, the transformative change (HCUITSI, 2021). The overall task of service-learning is "to inspire and empower" (ibid.).

Not only service-learning, as a concept, needs constant theoretical and practical revision; social work does, too. Th. O'Hare observes that "little work has been done to provide a conceptual model of social work practice that incorporates a broad array of (...) interdisciplinary influences (...)" (O'Hare, 2020, 3). Elaborating on the professional functions, he points out interventions that "comprise combinations of essential skills drawn from three major categories: (1) supportive skills (...); (2) cognitive behavioural coping skills (...); (3) case management skills (...)" (ibid., 4). Thus, service-learning is employed as an educational approach to develop and meet these demands in developing the multiple competencies of social workers. One more constituent part of social work education, empowerment, is viewed "not as a goal, but as a process" (ibid., 21). Through servicelearning, empowerment is developed in and endowed to the three parties: students, community members and academic staff, empowering themselves and others in the scope of their expertise and purposeful engagement.

\section{Discussion}

The overviewed complex and evolving concepts of service-learning and social work education require a discussion on the engaging reciprocity, demand trends and contexts, as requiring updated competencies for the academia and (pre-service) social workers, also requiring increasing awareness and agency from the community side.

In his book's chapter on service-learning, "Defining and Disturbing Service-Learning in Higher Education", D. W. Butin brings a stir to the common flow by enquiring what servicelearning "truly is" (Butin, 2010, 4). He articulates several questions in relation to the essence of service-learning: "Is service-learning a pedagogical strategy for better comprehension of course content? A philosophical stance commitment to the betterment of the local and/ or global community? An institutionalized mechanism fostering students' growth and self-awareness concerning responsibility? Or (...) a voyeuristic exploitation of the "cultural other" that masquerades as academically sanctioned "servant leadership" (...)?" (ibid.). The researcher asks these questions seeking to point out the needed balance between service and learning and to "link them in a meaningful way" (ibid., 5). He emphasises that "service-learning is never a singular, stable, or, ultimately, controllable practice (...)" (ibid., 4). Indeed, most of the presently reviewed literary sources have proven the latter observation. Much depends on the socio-educational approach to the competences of social workers-to-be and the demands of actual communities they intend to contribute to. As a pedagogical strategy, service-learning is a much-promising opportunity, if driven on the basis of both locally and globally identified and defined activity dimensions, contexts, expectations etc. in relation to social work and education in the field.

However, as concluded in the earlier paper on goals and experiences in implementation of service-learning, "[t]he paradigm shift of service-learning and critical service-learning, the transition in the approach to higher education led by the goal to educate professionals who are socially-conscious, active citizens capable of demonstrating their agency, having work-life skills and having experience-based knowledge of culture they are about to immerse in as professionals likely leading to a positive social change in society drive the educational innovation further" (Gruslyte, 2020, 208). Not leaving the community role aside, it is worth 
emphasising that reciprocity, partnership, shared wisdom and togetherness broaden the opportunities facilitated by the synergy.

Reviewing the ongoing scholarly investigations on service-learning in social work education, C. M. Lemieux and P. D. Allen conclude that "research lags far behind practice ideals" (Lemieux \& Allen, 2007, 321), "[s]ervice-learning in social work education is a pedagogical approach in need of more rigorous evaluation research to advance knowledge and to inform practice in the field" (ibid.). Being aware of continuous educational and social changes, they point out the need "to build theory from the design and conduct of servicelearning activities that produce meaningful outcome at all levels" (ibid., 312). Elaborating on the social work theory, D. Howe distinguishes two kinds of theory: theories for social work and theories of social work (Howe, 2016). The beneficial reciprocity of service-learning and social work education, as continuously developing, interacting and symbiotically generating processes, seeks to explore and implement both aspects, for and of, because these are the key points in approaching the complex phenomenon of the socio-educational reality. In this respect, the present paper attempted to display the diversity of approaches, treatment of service-learning as an educational philosophy, method, innovation technique in social work education as an area where social and educational demands and visions meet to generate the positive social change.

\section{References}

Barzelis, A., Barcytė, L., \& Mažeikienė, N. (2008). Tarpkultūrinès kompetencijos ugdymas ir raiška kooperuotose studijose (service-learning). In N. Mažeikienė (Comp.). Kooperuotu studijų sociokultūrine adaptacija Lietuvoje. Mokslo studija. (p. 262-327). Šiauliai: Šiaulių universiteto leidykla.

Butin, D. W. (2010). Service-Learning in Theory and Practice. The Future of Community Engagement in Higher Education. New York: Palgrave Macmillan.

Campbell, M. \& Bragg, N. (2007). The Bigger Picture: Social Work Educators' Role in Civic Engagement. In M. Nadel, V. Majewski, \& M. Sullivan-Cosetti (Eds). Social Work and Service Learning. Partnerships for Social Justice (p. 209-218). Plymouth: Rowman \& Littlefield Publishers, Inc.

Council on Social Work Education. (2015). 2015 Educational Policy and Accreditation Standards for Baccalaureate and Master's Social Work Programs. Retrieved from: https://www.uaf.edu/socwork/studentinformation/checklist/2015\%20EPAS\%20and\%20Glossary.pdf .

Embedding Service-Learning in Higher Education. Developing a Culture of Civic Engagement in Europe. (2019). P. Aramburuzabala, L. MacIlrath, \& H. Opazo (Eds). Routledge: Taylor \& Francis. DOI: https://doi.org/10.4324/9781315109053 .

Furco, A., \& Norvell, K. (2019). What Is Service Learning? Making Sense of the Pedagogy and Practice. In P. Aramburuzabala, L. MacIlrath, \& H. Opazo (Eds). Embedding ServiceLearning in Higher Education. Developing a Culture of Civic Engagement in Europe (p. 13-35). Routledge: Taylor \& Francis. DOI: https://doi.org/10.4324/9781315109053 .

Furuto, Sh. (2007). The Components of Service Learning as Pedagogy in Social Work Education. In M. Nadel, V. Majewski, \& M. Sullivan-Cosetti (Eds). Social Work and Service Learning. Partnerships for Social Justice (p. 21-39). Plymouth: Rowman \& Littlefield Publishers, Inc.

Global Social Work: Crossing Borders, Blurring Boundaries. (2014). H. Noble, H. Strauss, \& B. Littlechild (Eds). Sydney: Sydney University Press.

Gruslyte, M. (2020). Service-Learning in Higher Education: Experiences of Implementation in Lithuania. Society. Integration. Education. Proceedings of the International Scientific 
Conference, May 22-23, 2020, vol. 1, Rēzekne: Rezēknes technoloğiju akadēmija, p. 201210. DOI: http://dx.doi.org/10.17770/sie2020vol1.5078

How Can Universities Improve Their Social Impact. (2021). An international University World News webinar presented in association with the MasterCard Foundation. Retrieved from: https://www.youtube.com/watch?v=TNC82vuDgnI\&feature=youtu.be .

Howe, D. (2016). An Introduction to Social Work Theory. New York: Routledge: Taylor \& Francis.

Lemieux, C. M. \& Allen, P. D. (2007). Service Learning in Social Work Education: the State of Knowledge, Pedagogical Practicalities, and Practice Conundrums. Journal of Social Work Education, 43 (2), 309-325. Retrieved from http://www.jstor.org/stable/23044268

Majewski, V. (2007). Service Learning across the Social Work Curriculum. In M. Nadel, V. Majewski, \& M. Sullivan-Cosetti (Eds). Social Work and Service Learning. Partnerships for Social Justice (p. 41-57). Plymouth: Rowman \& Littlefield Publishers, Inc.

Mažeikienė, N. (2008). Projektas KOOPERIA: kooperuotu studijų (sevice-learning) adaptacija ir veiksmingumo tyrimas. In N. Mažeikienè (Comp.). Kooperuotu studiju sociokultūrinè adaptacija Lietuvoje. Mokslo studija (p. 6-29). Šiauliai: Šiaulių universiteto leidykla.

Mažeikienė, N., Ruškus, J. \& Vandzinskaitè, D. (2008). Kooperuotų studijų (service-learning) edukacinis poveikis: projekto KOOPERIA dalyvių apklausos rezultatai. In N. Mažeikienė. (Comp.). Kooperuotu studiju sociokultūrine adaptacija Lietuvoje. Mokslo studija (p. 215261). Šiauliai: Šiaulių universiteto leidykla.

Mažeikis, G. \& Lenkauskaite, J. (2008). Kooperuotų studijų (service-learning) adaptavimas Lietuvoje hermeneutinès pedagogikos požiūriu. In N. Mažeikienè. (Comp.). Kooperuotu studiju sociokultūrine adaptacija Lietuvoje. Mokslo studija (p. 30-104). Šiauliai: Šiaulių universiteto leidykla.

Mitchell, D. T. (2007). Critical Service-Learning as Social Justice Education: A Case Study of the Citizen Scholars Program. Equity \& Excellence in Education, 40, 101-112. DOI: https://doi.org/10.1080/10665680701228797

Mitchell, D. T. (2008). Traditional vs. Critical Service-Learning: Engaging the Literature to Differentiate Two Models. Michigan Journal of Community Service Learning, Spring 2008, p. 55-65. Retrieved from https://files.eric.ed.gov/fulltext/EJ831374.pdf

Noble, C. \& Henrickson, M. (2014). Towards Identifying a Philosophical Social Work. In H. Noble, H. Strauss, B. Littlechild (Eds). Global Social Work: Crossing Borders, Blurring Boundaries (p. 3-14). Sydney: Sydney University Press.

O'Hare, Th. (2020). Essential Skills of Social Work Practice. Assessment, Intervention, and Evaluation. $3^{\text {rd }}$ ed. Oxford: Oxford University Press.

Poulin, J., Matis, S. (2015). Social Work Competencies and Multidimensional Assessment. The Journal of Baccalaureate Social Work, 20, 117-135. Retrieved from: https://www.bu.edu/ssw/files/2017/07/Social-work-competencies-and-multidimensionalassessment-Poulin-and-Matis.pdf .

Phillips, A. (2007). Service Learning and Social Work Education: A Natural but Tenuous Connection. In M. Nadel, V. Majewski, \& M. Sullivan-Cosetti (Eds). Social Work and Service Learning. Partnerships for Social Justice (p. 3-19). Plymouth: Rowman \& Littlefield Publishers, Inc.

Preradović, N. M. \& Mažeikienė, N. (2019). Service Leaning in Post-communist Countries: Lithuania and Croatia. In P. Aramburuzabala, L. MacIlrath, \& H. Opazo (Eds). Embedding Service-Learning in Higher Education. Developing a Culture of Civic Engagement in Europe (p. 180-195). Routledge: Taylor \& Francis, DOI: https://doi.org/10.4324/9781315109053.

Vandzinskaitè, D. (2011). Mokymosi tarnaujant bendruomenei sociokultūrinè adaptacija Lietuvos universitete. Daktaro disertacija. Šiauliai: Šiaulių universiteto leidykla. 